\title{
APOE*4 Allele
}

National Cancer Institute

\section{Source}

National Cancer Institute. APOE*4 Allele. NCI Thesaurus. Code C105362.

Human APOE* 4 allele is located in the vicinity of $19 q 13.2$ and is approximately 4 kb in length. This allele, which encodes apolipoprotein $\mathrm{E} 4$, plays a role in triglyceride metabolism. The allele is associated with increased occurrence of both Alzheimer disease and coronary artery disease. 